\title{
Diabetic Ketoacidosis and Intensive Care
}

\author{
Gauri Raman Gangakhedkar
}

\begin{abstract}
Diabetic ketoacidosis (DKA) is one of the most common hyperglycemic complications of diabetes mellitus (DM) that is encountered in clinical practice as anesthesiologists and intensivists. Various stressors can lead to DKA in a diabetic patient, but it also remains a common manifestation at the outset of the disease among young diabetics. Thorough knowledge of the disease pathophysiology and treatment modalities help to reduce both duration of ICU stay and the morbidity and mortality associated with DKA.
\end{abstract}

Keywords: Complication, Diabetes, Diabetic ketoacidosis, Intensive care.

Research and Innovation in Anesthesia (2019): 10.5005/jp-journals-10049-0072

\section{Introduction ANd Epidemiology}

Diabetic ketoacidosis (DKA), which is the most common hyperglycemic complication of type I diabetes mellitus (DM), is defined as an acute metabolic complication of diabetes which comprises a biochemical triad of hyperglycemia (plasma glucose $>250 \mathrm{mg} / \mathrm{dL}$ ), hyperketonemia (urine acetoacetate + ), and metabolic acidosis $(\mathrm{pH}<7.3){ }^{1}$

Diabetic ketoacidosis has been found to the second most common presenting symptom of type I DM, with figures varying from $15 \%$ to $67 \% .^{2}$ This is particularly true in patients under the age of 6 years, where up to $44 \%$ of the children were found to present with DKA. ${ }^{3}$ However, there is an increase in the incidence of "ketone prone type 2 DM (T2DM) syndrome" also known as "Flatbush Diabetes". ${ }^{4}$ Though this variant has been primarily found in obese, African-Americans, its incidence is gradually increasing across all ethnicities.

\section{Pathophysiology}

Diabetic ketoacidosis represents an absolute or relative insulin deficiency with the body having to resort to the use of amino acids and triglycerides as sources of energy. The relative insufficiency of insulin occurs when physiologic or pharmacologic stressors push the insulin balance such that the demand far exceeds the supply. Table 1 given below indicates the common stressors. ${ }^{1,4-6}$

Absolute deficiency is usually caused by slips of administration of insulin among diagnosed diabetics.

There is also an increase in insulin counter regulatory hormones, such as, glucagon, glucocorticoids, catecholamines,

Table 1: Common stressors

\begin{tabular}{lll}
\hline S. no. & Physiologic & Pharmacologic \\
\hline 1 & Acute infection* & Corticosteroids \\
2 & Myocardial infarction & Thiazide diuretics \\
3 & Stroke & Sympathomimetics \\
4 & Pancreatitis & Sodium glucose co-transporter \\
& & 2 (SGLT-2) inhibitors \\
5 & Trauma & Malfunction of subcutaneous \\
& & insulin pumps \\
\hline
\end{tabular}

${ }^{*}$ Most commonly, lower respiratory tract infection, urinary tract infection
Department of Anesthesiology, Seth GS Medical College and KEM Hospital, Mumbai, Maharashtra, India

Corresponding Author: Gauri Raman Gangakhedkar, Department of Anesthesiology, Seth GS Medical College and KEM Hospital, Mumbai, Maharashtra, India, Phone: +91 9096266328, e-mail: gauri2903@gmail. com

How to cite this article: Gangakhedkar GR. Diabetic Ketoacidosis and Intensive Care. Res Inno in Anesth 2019;4(2):29-31.

Source of support: Nil

Conflict of interest: None

and growth hormones. The breakdown of triglycerides for energy leads to increased glycerol and fatty acids, while muscle break down leads to increased alanine levels. The glucagon stimulates hepatic gluconeogenesis using glycerol and alanine while fatty acids are now converted to ketones by mitochondria. The insulin deficiency causes unhindered ketosis which would normally have a negative regulatory effect. Additionally, there is impaired glucose utilization in the periphery. This acute metabolic imbalance results in the ketosis, acidosis, and hyperglycemia, which herald the DKA. ${ }^{1,5}$ Recent evidence suggests that DKA is a severe inflammatory state characterized by an elevation of proinflammatory cytokines (tumor necrosis factor-a and interleukin- $\beta,-6$, and -8 ), C-reactive protein, reactive oxygen species, and lipid peroxidation. ${ }^{7}$

Hyperglycemia results in osmotic diuresis, with a loss of free water and electrolytes resulting in dehydration. Ketosis is due to strong organic acids, acetoacetic acid, and $\beta$-hydroxybutyric acid, which contribute to the acidosis.

Patients present with symptoms, which include, but are not restricted to, a rapidly evolving, polyuria, polydipsia, weight loss, nausea, vomiting, and abdominal pain., ${ }^{1,2} 8$ Mental obtundation, though more common with HHS, can also be found with DKA, on account of severe systemic acidosis and hyperosmolarity. ${ }^{9}$ Cerebral edema is a rare complication of DKA, in young children, with an incidence of 6.8 per 1000 episodes and a mortality of $24 \% .{ }^{10}$

\section{Classification}

The American Diabetes Association (ADA) classifies DKA into mild, moderate, and severe as shown below (Table 2). ${ }^{1}$

o The Author(s). 2019 Open Access This article is distributed under the terms of the Creative Commons Attribution 4.0 International License (https://creativecommons. org/licenses/by-nc/4.0/), which permits unrestricted use, distribution, and non-commercial reproduction in any medium, provided you give appropriate credit to the original author(s) and the source, provide a link to the Creative Commons license, and indicate if changes were made. The Creative Commons Public Domain Dedication waiver (http://creativecommons.org/publicdomain/zero/1.0/) applies to the data made available in this article, unless otherwise stated. 
Diabetic Ketoacidosis and Intensive Care

Table 2: American Diabetic Association classification of DKA

\begin{tabular}{llll}
\hline & $\begin{array}{l}\text { Mild (plasma } \\
\text { glucose } \\
>250 \mathrm{mg} / \mathrm{dL} \text { ) }\end{array}$ & $\begin{array}{l}\text { Moderate } \\
\text { (plasma glucose } \\
>250 \mathrm{mg} / \mathrm{dL})\end{array}$ & $\begin{array}{l}\text { Severe (plasma } \\
\text { glucose } \\
>250 \mathrm{mg} / \mathrm{dL} \text { ) }\end{array}$ \\
\hline $\begin{array}{l}\text { Arterial } \mathrm{pH} \\
\begin{array}{l}\text { Serum bicarbonate } \\
(\mathrm{mEq} / \mathrm{L})\end{array}\end{array}$ & $\begin{array}{l}7.25-7.30 \\
7.00 \mathrm{to}<7.24\end{array}$ & $<7.00$ \\
$\begin{array}{l}\text { Urine ketone } \\
\text { Serum ketone }\end{array}$ & Positive & Positive & Positive \\
$\begin{array}{l}\text { Effective serum } \\
\text { osmolality }\end{array}$ & Positive & Positive & Positive \\
$\begin{array}{l}\text { Anion gap } \\
\text { Mental status }\end{array}$ & Variable & Variable \\
\hline & Alert & Alert/drowsy & Stupor/coma \\
\hline
\end{tabular}

\section{Treatment T, $^{11-13}$}

The treatment of DKA is targeted to correct the dehydration, acidosis, hyperglycemia, and reverse the process of ketosis. At the same time, monitoring for dyselectrolytemia and other complications of DKA is vital.

- Dehydration: Fluid deficit correction to improve organ perfusion is the first priority. Fluid therapy should be aimed at the correction of fluid deficit over $24-48$ hours. The fluid of choice is $0.9 \% \mathrm{NaCl}$ and the preferred rates of correction are as given below.

\begin{tabular}{ll}
\hline Fluid & Volume and rate \\
\hline Sodium chloride $0.9 \%$ & $1 \mathrm{~L}$ or $1000 \mathrm{~mL}$ over first hour \\
Sodium chloride $0.9 \% 1 \mathrm{~L}$ with & $3000 \mathrm{~mL}$ at the rate of $500 \mathrm{~mL}$ \\
potassium chloride & per hour over next 6 hours \\
Sodium chloride $0.9 \% 1 \mathrm{~L}$ with & $\begin{array}{l}2000 \mathrm{~mL} \text { at the rate of } 250 \mathrm{~mL} \\
\text { per hour over next } 8 \text { hours }\end{array}$ \\
\hline
\end{tabular}

- Hyperglycemia: After confirming a baseline serum potassium level of $3.3 \mathrm{mmol} / \mathrm{L}$, insulin is administered as a weight-based, fixed rate intravenous infusion, started at $0.1 \mathrm{U} / \mathrm{kg}$ bolus followed by $0.1 \mathrm{U} / \mathrm{kg} / \mathrm{hour}$ infusion.In patients who are known diabetics, taking insulin, long acting basal insulin, human or analog, may be continued. ${ }^{11}$ Low dose $(0.05 \mathrm{U} / \mathrm{kg})$ insulin has been studied as an alternative to the internationally recommended dose. The results suggest that the use of low dose did not significantly alter the outcome. However, both the studies were open label studies with small sample sizes, and therefore, larger studies are necessary to draw a relevant conclusion. ${ }^{14,15}$ Five percent dextrose should be added to the intravenous infusion when blood glucose level falls below $200 \mathrm{mg} / \mathrm{dL}$ as per the ADA. The Joint British Diabetes Societies for inpatient care guideline differ in its recommendation such that they advise addition on $10 \%$ dextrose when the sugar level falls below $250 \mathrm{mg} / \mathrm{dL}$. ${ }^{1}$ Recent evidence suggests that there is no difference in the outcomes with either, but the incidence of hyperglycemia is more with the use of $10 \%$ dextrose. ${ }^{1}$

- Dyselectrolytemia: Infusion of insulin causes hypokalemia due to intracellular migration of potassium. Table given below depicts the recommended rate of potassium supplementation (Table 3).

- Acidosis: There is no evidence to recommend the infusion of sodium bicarbonate unless faced with life-threatening hyperkalemia or severe acidosis $(\mathrm{pH}<6.9)$ along with impaired cardiac motility. ${ }^{15}$
Table 3: Rate of potassium supplementation

\begin{tabular}{ll}
\hline $\begin{array}{l}\text { Serum potassium in first } \\
24 \text { hours }(\mathrm{mmol} / \mathrm{L})\end{array}$ & $\begin{array}{l}\text { Potassium concentration in infusion } \\
\text { solution }(\mathrm{mmol} / \mathrm{L})\end{array}$ \\
\hline$>5.5$ & 0 \\
$3.5-5.5$ & 40 \\
$<3.5$ & $>40$ (requires senior clinical review) \\
\hline
\end{tabular}

- Phosphates: Decreased phosphate intake, movement of phosphate into extracellular fluid in response to acidosis, and phosphaturia can result in hypophosphatemia. Supplementation is advised in the face of severe hypophosphatemia $(<1 \mathrm{mg} / \mathrm{dL})$ with impaired cardiac motility, hemolytic anemia, and respiratory depression, in the dose of $20-30 \mathrm{mmol} / \mathrm{L}$ of intravenous fluid.

- Calcium and magnesium: Mild hypocalcemia and hypomagnesemia may occur, which must be monitored and treated.

- Treating the trigger: The trigger or the source of infection that caused the DKA must be investigated, isolated, and then treated. Since the most common cause is infections, appropriate antibiotics must be started.

The role of glargine insulin and intravenous thiamine in the management of DKA is being investigated. ${ }^{1}$ Hourly clinical and biochemical monitoring of serum electrolytes and blood gas analysis is recommended to track the therapeutic progress. The presence of indicators, such as, arterial $\mathrm{pH}<7.1$, blood ketones $<6.0 \mathrm{mmol} / \mathrm{L}$, serum bicarbonate $<5 \mathrm{mmol} / \mathrm{L}$, serum potassium $<3.5 \mathrm{mmol} / \mathrm{L}$, impaired consciousness, saturation $<92 \%$, and hemodynamic compromise, demands the need for critical care. ${ }^{11}$

Regular, consistent monitoring is necessary till evidence of resolution can be obtained. Markers of resolution include ${ }^{11,12}$

- Plasma glucose $<200 \mathrm{mg} / \mathrm{dL}$

- Venous $\mathrm{pH}>7.3$

- Serum bicarbonate $>18 \mathrm{mEq} / \mathrm{L}$

- Anion gap $<10$

- Blood ketones $<3.49 \mathrm{mg} / \mathrm{dL}$

Urine ketostix forms an essential part of diagnosing DKA but is not recommended for monitoring since they only detect the acetoacetate in the urine. $\beta$-hydroxybutyrate is predominantly present in the blood and gets converted to acetoacetate. This could lead to a false impression of nonresolution of DKA. ${ }^{11}$

Transition to multiple doses of subcutaneous insulin is usually done when the DKA has resolved and the patient has started eating. The ADA recommends the switch when at least two of the following criteria are met: anion gap $<12 \mathrm{mEq} / \mathrm{L}$, serum bicarbonate $>15 \mathrm{mEq} / \mathrm{L}$, and $\mathrm{pH}>7.3 .^{11}$ Intravenous insulin is continued for two hours after initiation of subcutaneous therapy to prevent rebound hyperglycemia. Patients who were already on insulin before the episode can go back to their previous regimens. Insulin naïve patients are usually started with a weight-based subcutaneous regimen, using a total dose of $0.5-0.7 \mathrm{U} / \mathrm{kg} /$ day, giving $50 \%$ of the total dose as once daily basal insulin and dividing the other $50 \%$ equally between prebreakfast, prelunch, and presupper doses of rapid acting insulin.,11,12 Till the patients are able to start oral feeds, intravenous infusions are the best therapeutic regimen.

\section{Prognosis and Outcomes}

The incidence of DKA is increasing and it accounted for over 1,60,000 hospital admissions in 2017, in the USA alone. 'The annual burden in 
the USA due to DKA is estimated at a staggering $\$ 2.4 \mathrm{bn} .{ }^{16}$ However, with the advent of point-of-care monitoring and availability of prompt medical attention, the mortality with DKA has reduced to $<1 \%$ in most populations except those with major systemic illness and those with advanced ages. ${ }^{17}$ The average length of hospital stay has reduced from 5.7 to 3.4 days with shorter durations of stay required in those admitted due to lapses in insulin administration. ${ }^{18}$ The in-hospital mortality has been found to be significantly higher in patients who were not on insulin therapy. ${ }^{19}$ While the statistical evidence points to improved outcomes after intensive care unit admissions, the 5 -year readmission and mortality remain at $46.4 \%$ and $35 \%$, respectively, thus proving that early targeted interventions may be the only way to reduce the morbidity and burden caused by this illness. ${ }^{20}$

\section{References}

1. Karslioglu French E, Donihi AC, Korytkowski MT. Diabetic ketoacidosis and hyperosmolar hyperglycemic syndrome: review of acute decompensated diabetes in adult patients. BMJ 2019;365:11114. DOI: 10.1136/bmj.I1114.

2. Klingensmith GJ, Tamborlane WV, Wood J, et al. Pediatric diabetes consortium. diabetic ketoacidosis at diabetes onset: still an all too common threat in youth. J Pediatr 2013;162(2):330-4.e1. DOI: 10.1016/j. jpeds.2012.06.058.

3. Quinn M, Fleischman A, Rosner B, et al. Characteristics at diagnosis of type 1 diabetes in children younger than 6 years. J Pediatr 2006;148(3):366-371. DOI: 10.1016/j.jpeds.2005.10.029.

4. Endocrine problems in the critically ill 1: diabetes and glycaemic control. BJA.

5. Brutsaert E, (2019). Diabetic Ketoacidosis (DKA) - Endocrine and Metabolic Disorders - MSD Manual Professional Edition. Retrieved 20 November 2019, from https://www.msdmanuals.com/en-in/ professional/endocrine-and-metabolic-disorders/diabetes-mellitusand-disorders-of-carbohydrate-metabolism/diabetic-ketoacidosisdka.

6. Peden NR, Braaten JT, McKendry JB. Diabetic ketoacidosis during long-term treatment with continuous subcutaneous insulin infusion. Diabetes Care 1984;7(1):1-5. DOI: 10.2337/diacare.7.1.1.

7. Malone ML, Gennis V, Goodwin JS. Characteristics of diabetic ketoacidosis in older versus younger adults. J Am Geriatr Soc 1992;40(11):1100-1104. DOI: 10.1111/j.1532-5415.1992.tb01797.x.

8. Nyenwe EA, Razavi LN, Kitabchi AE, et al. Acidosis: the prime determinant of depressed sensorium in diabetic ketoacidosis.
Diabetes Care 2010;33(8):1837-1839. DOI: 10.2337/dc100102.

9. Edge JA, Hawkins MM, Winter DL, et al. The risk and outcome of cerebral oedema developing during diabetic ketoacidosis. Arch Dis Child 2001;85(1):16-22. DOI: 10.1136/adc.85.1.16.

10. Dhatariya KK. Diabetic ketoacidosis and hyperosmolar crisis in adults. Medicine 2019;47(1):46-51. DOI: 10.1016/j.mpmed.2018.10.001.

11. Kitabchi AE, Umpierrez GE, Miles JM, et al. Hyperglycemic crises in adult patients with diabetes: a consensus statement from the American Diabetes Association. Diabetes Care 2009;32(7):1335-1343. DOI: 10.2337/dc09-9032.

12. Wolfsdorf Jl, Glaser N, Agus M, et al. ISPAD clinical practice consensus guidelines 2018: diabetic ketoacidosis and the hyperglycemic hyperosmolar state. Pediatr Diabetes 2018;19(Suppl 27):155-177. DOI: 10.1111/pedi.12701.

13. Nallasamy K, Jayashree M, Singhi S, et al. Low-dose vs standarddose insulin in pediatric diabetic ketoacidosis: a randomized clinical trial. JAMA Pediatr 2014;168(11):999-1005. DOI: 10.1001/ jamapediatrics.2014.1211.

14. Puttha R, Cooke D, Subbarayan A, et al. North west England paediatric diabetes network. low dose $(0.05$ units $/ \mathrm{kg} / \mathrm{h})$ is comparable with standard dose $(0.1 \mathrm{units} / \mathrm{kg} / \mathrm{h})$ intravenous insulin infusion for the initial treatment of diabetic ketoacidosis in children with type 1 diabetes-an observational study. Pediatr Diabetes 2010;11(1):12-17. DOI: 10.1111/j.1399-5448.2009.00536.x.

15. Chua HR, Schneider A, Bellomo R. Bicarbonate in diabetic ketoacidosis - a systematic review. Ann Intensive Care 2011;1(1):23. DOI: 10.1186/2110-5820-1-23.

16. Dhatariya KK, Umpierrez GE. Guidelines for management of diabetic ketoacidosis: time to revise? Lancet Diabetes Endocrinol 2017;5(5):321-323. DOI: 10.1016/S2213-8587(17)30093-1.

17. Zhong VW, Juhaeri J, Mayer-Davis EJ. Trends in hospital admission for diabetic ketoacidosis in adults with type 1 and type 2 diabetes in England, 1998-2013: a retrospective cohort study. Diabetes Care 2018;41(9):1870-1877. DOI: 10.2337/dc17-1583.

18. Mendez Y, Surani S, Varon J. Diabetic ketoacidosis: treatment in the intensive care unit or general medical/surgical ward? World J Diabetes 2017;8(2):40-44. DOI: 10.4239/wjd.v8.i2.40.

19. Venkatesh B, Pilcher D, Prins J, et al. Incidence and outcome of adults with diabetic ketoacidosis admitted to ICUs in Australia and New Zealand. Crit Care 2015;19(1):451. DOI: 10.1186/s13054-015-1171-7.

20. Ramaesh A. Incidence and long-term outcomes of adult patients with diabetic ketoacidosis admitted to intensive care: a retrospective cohort study. J Intensive Care Soc 2016;17(3):222-233. DOI: $10.1177 / 1751143716644458$. 